\title{
LENDO INTERTEXTOS: O PARANÁ E SUAS MÚLTIPLAS IDENTIDADES
}

\author{
OLIVEIRA, Márcio de; SZWAKO, José Eduardo Léon (orgs). \\ Ensaios de sociologia e história intelectual do Paraná. \\ Curitiba: Ed. UFPR, 2009.
}

\section{POR}

\section{Ana Cleide Chiarotti Cesário ${ }^{1}$ Ana Maria Chiarotti de Almeida ${ }^{2}$}

\begin{abstract}
coletânea Ensaios de sociologia e bistória intelectual do Paraná, organizada por José Eduardo Léon Szwako e Márcio de Oliveira, cientistas 1 sociais da UFPR, reúne trabalhos de estudiosos paranaenses das áreas de Ciências Sociais, História, Literatura e Artes, que abordam a equação História, Sociologia Intelectual e Paraná. Trata-se de um olhar dirigido tanto à história intelectual como à história social das idéias. Organiza-se em quatro sessões: Paraná: Sociologia e História; Ideologias e Identidades Políticas; Literatura e Artes; Museus e Produção da Memória.
\end{abstract}

Na primeira, o ensaio Por uma sociologia do Brasil Meridional, Oliveira discute 0 movimento Paranista enquanto formador de uma identidade social e

\footnotetext{
${ }^{1}$ Professora do Departamento de Ciências Sociais da Universidade Estadual de Londrina. Doutora em Ciência Política pela USP/São Paulo. End. Eletrônico: ana.cesario@uel.br

${ }^{2}$ Professora do Departamento de Ciências Sociais da Universidade Estadual de Londrina. Doutora em Sociologia pela USP/São Paulo. End. Eletrônico: ana.ch@uel.br
} 
cultural da Província. Baseado no ideário de Romário Martins e seus seguidores, o Paranismo fundamenta um regionalismo, base para um tipo particular de sociologia do Brasil Meridional.

Entre East River e o Iguaçu: o projeto dos irmãos Rebouças para a província do Paraná de Dantas analisa a trajetória de dois irmãos engenheiros militares baianos e afro-descendentes. Defendem a segurança das fronteiras e integração geopolítica da Província paranaense com países vizinhos. 0 tom abolicionista e reformista dos irmãos acentua o trabalho livre, iniciativa privada e modernização.

Szwako, no ensaio Paraná das etnias: ensaio sobre o racismo na produção intelectual de Bento Munhoz da Rocha, focaliza o pensamento do intelectual-político pertencente a uma das oligarquias paranaenses da Primeira República. Mostra como sua produção acentua uma formação ideológica de defesa da ordem burguesa, por meio do anticomunismo e mistificação do pioneirismo, produzindo sentidos de branqueamento da população sulina e de invisibilidade do negro.

A produção intelectual de Francisco Paz da UFPR é analisada por Pereira em Francisco Moraes Paz: uma poética viagem pela História. Ao realizar diálogo com as Ciências Sociais, Literatura e a Lingüística, o historiador voltase para a pequena história e a busca do significado das utopias libertárias. Um processo de compreensão que assume o desafio da polissemia dos discursos e a tensão que acompanha a produção dos sentidos.

Na segunda sessão, Codato e Oliveira em Catolicismo, liberalismo e política conservadora no Paraná nos anos sessenta analisam os movimentos a favor do ideário democrático liberal, político e econômico que antecedem o Golpe de 1964. Comparam a Marcha pela Família com Deus pela Liberdade (São Paulo) com a sua releitura em Curitiba - Marcha a Favor do Ensino Livre -, revelando a divisão ideológica do empresariado, da classe média e dos católicos conservadores contra o comunismo e populismo.

Em A "TRIBUNA DO POVO" e os comunistas paranaenses, Kieller e Oliveira demonstram a importância do jornal curitibano (1949-1964) como veículo de organização, disseminação e unificação da política oficial do PCB. Porta-voz dos movimentos urbanos e campesinos de esquerda envolvia-se com os grandes debates ideológicos da época e divulgava informações culturais e propagandas partidárias. 
No ensaio Militância feminina no Paraná: a construção de uma identidade (1945-1956) Zeni analisa a ampliação dos quadros femininos no PCB do Paraná, pós $2^{a}$ Grande Guerra. As Uniões Femininas, dentro das células e comitês, afirmam a cidadania e lutam pela liberdade por meio da solidariedade grupal e do rompimento da opressão. Engajam-se nos debates e campanhas mundiais e nacionais do partido.

Imprensa e política no Paraná: uma biografia coletiva dos redatores republicanos de Corrêa analisa, utilizando método prosográfico, um conjunto de dez jornalistas redatores paranaenses com influência no ideário republicano. 0 ensaio evidencia a importância das famílias, das redes de sociabilidade e do litoral como berço do movimento republicano no estado.

$\mathrm{Na}$ terceira sessão, Gil em Notas sobre as Aporias da Literatura no Paraná (ou o porquê de a literatura do Paraná não ter a sua bistória) considera que a inexistência de uma história literária paranaense relaciona-se à fragilidade político-econômica e formação histórico-social descontínua do estado. Há uma ausência de identidade própria, com interlocução cosmopolita, além das fronteiras paranaenses.

Silvestrin em Das Artes e dos Ofícios dos Homens de Letras Paranaenses: o olhar de Mariana Coelho focaliza a obra 0 Paraná Mental da ensaísta portuguesa, que aborda três gerações de literatos paranaenses, revelando a dinâmica cultural de Curitiba e a luta por identidade regional. Com olhar crítico e participação ativa na vida pública, Mariana enfrenta o preconceito por defender idéias feministas, 0 socialismo e a democracia.

O caminho percorrido por Frederico Lange de Morretes (1892-1954), de Salturi, analisa a trajetória do artista-cientista, especialista em botânica, malacologia e paleontologia. Junto com outros artistas desenvolve o estilo Paranista nas artes. A figura estilizada do pinheiro constitui o tema principal de suas obras. Ajuda a fundar na década de 1930 a Sociedade dos Artistas do Paraná, liderando movimento político e sindical contra a subordinação da arte à política da Interventoria.

Camargo analisa O Salão Paranaense de Belas Artes, fundado em 1944. Em sua décima quarta edição (1957) emerge oposição entre o grupo dos acadêmicos (impressionistas) e o grupo dos modernos (abstracionistas), formado por jovens artistas, que em 1960 projetam-se no Salão e na direção do Departamento de Cultura do Estado. 
Dos Cavaletes às metalúrgicas: uma análise geracional nos caminhos da arte em Curitiba, de Gassen, focaliza o meio artístico de Curitiba entre 19601990. Até 1960 prevalece a hegemonia de artistas consagrados. A partir de 1970 surgem, em torno de galerias, como a Cocaco, ações coletivas de jovens artistas, que utilizam linguagens e materiais alternativos como a metalurgia, por maior participação em associações e conselhos, em busca de identidade profissional pósditadura militar.

Na quarta sessão, Kersten em Patrimônio cultural, a presentificação da história e da memória no Paraná enfatiza os aspectos simbólicos do patrimônio. Combina estudo histórico e antropológico. Acentua o pioneirismo do Estado em instituir políticas públicas de tombamento e defesa do patrimônio cultural, contemplando a diversidade étnica, a paisagem urbana e a preservação de bens naturais.

No ensaio Conhecendo o bomem e a paisagem paranaense: o Museu Paranaense e o desenvolvimento das ciências sociais e naturais no Paraná entre as décadas de 1940-1950, Maranhão revela a ligação entre o Museu Paranaense e a Faculdade de Filosofia Ciências e Letras da UFPR. 0 professor médico e antropólogo José Fernando Loureiro contribui com pesquisas etnográficas e paleontológicas, transformando o Museu em laboratório para a formação de futuros pesquisadores e professores.

Em O lugar do popular e do folclórico no Museu de Arqueologia e Etnologia da UFPR, de Sallas, José Loureiro Fernandes emerge como mentor da criação do Museu de Artes Populares e Arqueologia de Paranaguá - 1950-1960 (UFPR) - antigo Colégio Jesuíta. Institucionaliza o folclore e a antropologia na academia e influencia a primeira exposição do Museu que tematiza o "popular" como expressão da cultura e folclore nacionais. Na segunda exposição (1995), prevalece $o$ regional e a cultura local.

No último, Vladimir Kozák e suas imagens, Rosatto interpreta conjunto de fotos dos Xetá e outros grupos indígenas, do engenheiro Kozák, imigrante da Tchecoslováquia e foto-cinegrafista da UFPR. Enquanto "fotografia etnográfica" e metáforas das sociabilidades, as imagens revelam a experiência compartilhada de autorrepresentação e do jogo interacional entre fotógrafo/fotografado, a experiência vivida em sua construção ... uma imersão compartilhada de sentidos e significados. 
A partir do caso paranaense, a coletânea levanta questões atuais e importantes para o pensamento social político cultural. Dentre elas emerge 0 das relações raciais assimétricas ocultadas pelo mito da democracia racial e de um "Brasil branco e europeu"; a pertinência da construção de um referencial regionalista se sobrepondo à nacionalidade; a reificação das clivagens regionais, representações há muito incorporadas no imaginário dos paranaenses, que já comportou, dependendo do lugar ocupado pelo analista, um tipo de leitura marcada pela oposição Paraná Tradicional e Paraná Moderno.

Na tentativa de construir, no plano simbólico, uma interpretação de síntese acerca da multiplicidade da vida intelectual paranaense, a coletânea acaba por produzir um olhar prevalente da capital do Estado sobre outras localidades. Tal orientação pode produzir, no leitor, a falsa impressão de que no interior paranaense, em regiões e cidades novas, não houve ou não há movimentos políticos, culturais e artístico-literários também responsáveis pela formação da história intelectual e das idéias no Paraná. Por isso, entendemos que a publicação desta coletânea deve ser estímulo para outras abordagens e interpretações sobre o tema proposto. 